\title{
Analytical Study on Social Change in Tunisia from the Pre-colonial Period to Arab Spring
}

\author{
Hamda Ghalib M. G. Almheiri \\ Abdi O. Shuriye \\ International Islamic University \\ Malaysia
}

\begin{abstract}
There are natural forces of circumstances that control human system; inclination of change in man is very high and quick, however, occurrence of change has become constant and unchanging nature of life. In fact, that has become permanent phenomenon in human society. What are the components that changes in man's life, behavior and characters, dogmas and beliefs, customs, norms and values, or all together? This research aims to provide an answer to the above question, through the study of radical socio-political changes in Tunisia from Precolonial Period until 2011 Revolution. Tunisia which is one of the most beautiful society, and the model of profound radical change at times, such as the revolution that sparked the Arab Spring (al-Raī'u al-'Arabi) which is expected to change the Arabs world in twenty years or more, and in another time, an example of gradual change that takes a long time, as it happened during the time of independence and Bourguiba's negotiation with the French colonists. In fact, Tunisia is claimed to be considered as the citadel of the West and the model that all the countries of the South must adopt and follow. This research has revealed that the phenomenon of radical change has occurred twice in Tunisia after its independence in 1956: first: when Habib Bourguiba issued the family code after four months from the independence, in which he abolished the legitimate provisions that related to religion and faith of the citizens by the force of law, and consequently followed by the series of decisions until the end of Bin Ali's reign, secondly: when Bu'azizzi set fire on himself, in fact as if he set the whole Arabs world ablaze. The research has figured out that Tunisia has been a pioneer in many fields, including its leadership in the establishment of the first educational institution in the sense of the university - Zaytuna University, it also pioneered the application of a new concept in the ideological war waged against the Islamists; policy of the sources drains which has become an exemplary strategy in the global war on the terrorism, as well as its application to finance, liquidation and others. The research confirmed that there are some symbolic community titles and ranks such as mysticism leaders, chief Shürā of al-Mālikiyyah Council, first Imam of al-Zaytünah Mosque, representing the moral weight in Tunisian society and playing vital roles in the community as well, especially in reconciling and bringing people of different segments in the society together on the public interests. In addition, the public Awqâfroles were also very essential, where its activities did not only limit to the Tunisian citizens but there were also allotted amount to the two Holy Mosques (Makkah and Madinah Mosques). The research concluded that the change occurs in any given society through one of these ways: law, principle of education and force, and for different purposes, including: Human need for dignity and personal respect, social need for justice and political need for freedom. What usually changes in man is conduct, by changing the values governing behaviors, through the interference in people's identity, language and religion. In a nutshell, there is a definite effect between the system adopted by the authority and the impact of this system on the societal, economical and moral structures.
\end{abstract}

\section{Introduction}

Life is all about movement from one situation and condition to the other; there are changes that normally occur from various aspects of life, owing to the high and quick inclination of the man to diversity and variety. However, occurrence of change has become constant and unchanging nature of life; in fact, that has become a persistent phenomenon in any society. We will be addressing this issue by taking one of the most beautiful society which is Tunisian as a paradigm, through analyzing the diversities of its historical events within a specific period of time. 
Therefore, we admit that we stand humbly in front of the major facts that will be disclosed through this research; what are the factors of change, and how does it affect the man systems, such as institutions, conduct, dogma, norms, etc.? The variation that happens in the society over a given period of time, which is considered as social change, and definitions of the research terms and other concepts will be addressed in details. Radical change has occurred twice in Tunisia, since after its independence in 1956. First time: when Habib Bourguiba issued the family code or personal status after four months from independence, in which he abolished the legitimate provisions that related to religion and faith of the citizens by the force of law, and that was done without any challenge or opposition from the citizen. (Tunisian Personal Status Law). Subsequently, his government invaded the country with other series of decisions, mainly for the interest of small groups of people, while the majority of the citizens were following their daily routine of life without paying much attention to the issue. (Tunisia-Sat Forum). Second time came when Bu'azīzī set fire on himself, the phenomenon that actually served as if he has set the whole Arabs world ablaze. This incident has brought the exiles, prisoners, and disenfranchised people from every corner of the globe directly to the power. The scene that was indeed surreal to us. (Thomas Schiller, 2011, p. 6-7). The significant role of western occupation of the Arab countries must be put into consideration as one of the major factors of changes that occurred in their midst, from which the split and division of Arabs into different nationality emerged. Whereas, the system of nationality has served as a solution to European intractable problems, but when the same system was exported to Arabs world, it became a problem from which more crises arose, and the system even gained a greater holiness than all the heavenly books together. Surely, the land, society and law are very different in most aspects between the European worlds and the Eastern world of Muslims. ('Alī W.H, 2017).

\section{Image of Tunisian Society Before 1881 Colonization}

Tunisia seemed to be the Promised Land for the emerging colonialists with maritime power in the Mediterranean Sea and beyond, the territory that was then under the control of Phoenicians, Romans, Arabs, Spaniards, Turks and French as well. (Tunisia-Sat Forums, 2009). Tunisia is distinguished by its proximity to the northern Europe, with the safe and quiet coast with bays, shallow land, low terrain and wide roads in its highlands. (Hassan, 1373 A.H, P. 6). So, it is very normal and natural for the environment and geographical location to have an impact on the people's moral in terms of tolerance, acceptance of the others and integration. Thus, it is possible to say that, the integration between the warriors and some parts of Tunisians was normal, as we can also attribute the factor of their leniency to the geographical effects. However, the major factor was that a group of people saw their interest in stability, especially the urban groups in the offices, so they cooperated with the occupiers and exploited the advantage of Tunisian society, which its preference is for the peace and stability, while the rural areas were distinguished by being under the control of urban administrative and its military conquest as well. Inhabitants of the countryside are always in an enmity with the urban people and at all times look for any opportunity to strike their system, as that is also the common feature of some rebellions of these regions.

\section{Tunisia under the Ottoman Administration}

Ottomans defeated the Spaniards and conquered Tunisia. The conquest of the Turkish officers appointed directly from Istanbul served as an emergence of foreign class in Tunisia, distinguished by sovereignty derived from the naval military power. The Ottomans established security in Tunisian cities; however, they did not interfere in the rural system, so it remained on the practical independence and mock dependence on the central authority. Hence, Tunisia has actually become an independent province with a legal dependence on Astana. The Ottoman Empire was then divided into provinces, and the province in the Ottoman's administrative division was the highest administrative level worldwide between sixteenth and nineteenth century. Commitment of Turkish soldiers to protect Tunisian elites, get rid of the corrupted people, treat the citizens with justice, restore security and appoint Tunisians as advisers, as well as how they were keen to bring the systems of Islamic cities to the country, attained them support of the scholars which earned them more legitimacy. (Muhammad al-Hādī, 1993. P. 68-70).It can be noticed here, that Muslims' lives did not free at any time from military reverence, due to the conquests and victories gained by them for Islam. However, the military system had created an idea of linking with the personalities or charismatic leaders in the consciousness of next generation of Muslims, who are mostly from Arabs and others. Actually, there is no state without a leader in the sense of a modern European state, where the nation meant by the functional state that provides external and internal security for the citizens. 
Therefore, due to Arabs and Muslims' tribal system, they tend to non-hierarchical life and community institutions with a few administrative chains, that characterized by intimate relationship. Hence, you find them very creative in their relationship in a simple social environment and their connection to the people as their grandfathers used to associate with the tribal leaders.

\section{System of Government during the French Protection of Tunisian}

In 1881, Tunisian administration was formed under the supervision of French colonialists, where the anti-French members were distanced from the system and replaced with the French loyalists. There was also a plan for legal framework for the economic colonization started with the 1885 Real Estate Law, by regulating the text of Tunisian real estate's registration, and defending the rights of the internees and absentees, as well as translating of șukūk and other legal arguments relating to the real property's rights. The provision that was decreed as a final and irrevocable decision. Based on that law that was extracted from Australian law of Torrance, the wide areas of Tunisian land (Awqaf land) especially in the northern Tunisia were confiscated by French colonists.(Conveyancing and Law of Property Act 1881 and Muhammad al-Hādī, 1993. P. 100).

During that period, there was an Industrial Revolution which affected the global systems, hence Europe was in need of more wheat production, necessary raw materials for industries, ports for delivering of raw materials to their factories and markets for their goods, all which opened their eyes to focus on the North Africa. France also used the opportunity of embezzlement and financial malpractices of the Beys to establish its system in Tunisia, especially malpractices in the Ministry of Mușțafā Khazandār, which continued to request successive loans from foreign communities residing in Tunisia and foreign banks, the acts that also caused the bankruptcy of the nation treasury and loss of financial freedom, which led to imposing of foreign financial control on Tunisia in 1869 . In fact, Tunisiawas really occupied by foreign power, due to poor financial policy. (Husayn, 1373 A.H, p. 174-180). The French colonists presented to Muhammad al-Șādiq Bey the text of the Bardo Treaty, under which the French protection was imposed on Tunisia, and the pledge to protect al-Husaynī throne was also mentioned in the treaty. However, the crisis intensified in the country with the intervention of France, its establishment of railways for the merchandises' transportation, its control over the economy, trade, agriculture and education, and all governmental and community institutions, and likewise its confiscation of lands, especially Awqaf lands. Therefore, the country was in a dilemma, which led some cities and dignitaries to accept the new order, while the tribes of the middle south represented by Mayor Muhammad al-'Arabi Zarūq rose against the system. Zarūq who told the Bey to go to the capital and promised him to send sixty thousand fighters, but the Bey was afraid and later signed the treaty, thus Zarūq was impeached and went into exile to subsequently instigate resistance. (Husayn, 1373 A.H, p. 177179; Muhammad al-Hādī, 1993. P. 100-103).

\section{Tunisian Society during the Period of French Colonization}

Once the French colonization completed its control over all the sections in the state, Tunisian opposition movements established the cultural and political reform movements, by establishing al-Khaldūniyyah School as the first modern school that aimed to provide the modern civilized knowledge for its graduates. (Muhammad alHādī, 1993. P.110-113). Actually, there was a lapse or a kind of discrimination between the Beys, dignitaries and landowners among Tunisians and foreigners who are mostly French in one side, and among the public and their national and religious leaders in another side, particularly in terms of caring. The presence and roles of religious leaders should be noted here, especially when religion was an element used to legitimize rulers, even if he gained the power unconstitutionally and violently by coup. Religious groups in general had influence over general societal affairs, especially mystics, however, there was a rivalry in the midst of their leaders over leadership and money that led to the weakness of their influence. (Muhammad al-Hādī, 1993. P. 105). A name of jurist of power or Muftī of Sultān can be given to the official scholars holding the post in the name of religion, especially during the period of tyrant rulers. In this case, people themselves will automatically appoint a reliable mufti that can serve their purpose, so there will be formal authority that issues orders and laws, and another parallel authority that represents people's dreams and their true desires. In order to complete the image of Tunisian society, we must present the influential bodies in Tunisian system and discuss its social classes formation as well, especially the Beys, French occupiers and community ranks, such as the leaders of mysticism and their groups, al-Zawāyā, chief Shūrā of al-Mālikiyyah Council, first Imam of al-Zaytūnah Mosque, ranks of the elders and the heads of the legitimate Council as well, and the association of al-Ashrāf which its leader known as al-Naqīb (al-"Arïf), who is entrusted with the management of al-Hāshimī’s affairs (Prophet's lineage). 
Craftsmen were also recognized with a special community title which should be assigned only by issuing a signed proof registered in court record, as they also have many detailed and precise rights competing with the best human rights codes adopted by United Nations.

Their ranks started from the lower to the higher status, i.e. boy, then employee, then manufacturer and the teacher. Those ranks mentioned usually play vital roles in the community, especially in reconciling and bringing people of different segments in the society together on the public interest. However, they serve as the source of moral and values for the society to remain balanced through their psychological effect on the public. In order to complete that image, the roles of Waqf foundation should be discussed, as it plays a vital role in organizing social and economic development system, social insurance, individual savings and insurance policy for successive generations. Activities of Tunisian Public Awqāf included different kinds of benevolence, such as the establishment of shelters, hospitals, schools, children's circumcision, provision for the poor ones, organization of marriage for the bachelors and spinsters, maintenance of the mosques, protection of the cities and boarders by protecting the fortresses, fences and towers and supplying and equipping the ships, as it was the case in Sfax and elsewhere. Those Waqf benefits were not confined to the Tunisian citizen alone, but a certain share was also allotted to the two holy mosques, which was used to be distributed to various sections throughout the country. In fact, the Waqf provides for all needy people. (al-Mawsuah al-tunisiyyah).

\section{Al-Zaytūnah Foundation}

It comprises of the mosque, university, library and students' hostel. It was then with the total number of twenty thousand students. When the French colonists came to Tunisia, there was a fierce resistance from this institution that was known with its protection for the Arabic language and Islamic education as well. However, current statistics from the institution shows drastic fall-off in the number of students. Education had started in the institution since early of 517 A.H. Its history was full of production of many renowned scholars, who had filled the sky of Arabs and Muslims world with pride and admiration, such as 'Alī bin Ziyād, Asad bin al-Furāt, ImāmSuhnūn, Muhammad bin 'Arafah and 'Abd al-Rahman bin Khaldūn, as well as the leaders of mysticism, such as Abu al-Hasan al-Shādhlī and Ahmad al-Tījānī,likewise the reformers and innovators, such as Muhammad al-Ṭāhir bin 'Ashūr, Abdul 'Azīz al-Tha'alabī and al-Țāhir al-Haddād, as it produced al-Shaykh Al-Azhar, Shaykh Muhammad al-Khadir Husayn, Abdul Hamīd bin Bādīs and HawārīBūmidīn.(Husayn, 1373 A.H; Muhammad al-Hādī, 1993).

Those community institutions in addition to the family had have a profound impact on Tunisian society, in terms of ability to influence the public opinion, mobilize the community support, solve the problems of society effectively and making decision with or without the state institutions for the public interest. French colonists kept the Bey system as a camouflage and cover-up, while the actual power was in the hand of the head of French occupiers who was being assisted by civilian supervisors. They directly took over foreign affairs, defense and most of the financial issues. (Muhammad al-Hādī, 1993, P. 99-100). Big effort was put in developing the infrastructure, especially the mining basin for the extraction of phosphate. They built railways, post office, banks, camps and ports, as the control of the vast fertile agricultural lands was took by the colonists, especially those land that were under the control of Awqaf. They spent the resources of Islamic Waqf in particular on their own facilities and projects, which made the Awqaf most affected institution among the others. In fact, the French system of dealing with their colonies was characterized by insolence and arrogance. (Muhammad al-Hādī, 1993, P. 99-100 and 108).There was not a solid opposition to the colonialism in the early years of colonization due to the strict military law; however there were numbers of intellectuals led by 'AlīBāshHānabah and al-BashīrȘafar who established Tunisian youth movement to defend the rights of Tunisians. (Muhammad al-Hādī, 1993, P. 113). Consequently, protests escalated with the outbreak of al-Jalāaz events, when the French violated the sanctity of Islamic cemetery and scattered the graves. This event coincided with the boycott of Tunisians against the French tramway company, after a Tunisian child being struck by French and the culprit was not taken to the court, instead, the French response was a holding of trial for the participants of boycott. (Muhammad al-Hādī, 1993, P. 114). During this period, free Constitutional Party which called for the reform without independence was founded. The party that received an implicit support from al-Nāșir Bey, however the pressure of the French representative refrained the movement of the party, which eventually led its leader 'Abdu el-'Azīz al-Tha'alabì to exile. Then the General Confederation of Tunisian Workers (CGTT) emerged asthe first national union to include Tunisian workers, but its activities didn't continue for long, due to the clampdown and banishment of its founder Muhammad ‘Alī al-Hāmī. (Muhammad al-Hādī, 1993, P. 114-119). 
Subsequently, a group that completed its education at the various French universities, including al-Habīb Bourguiba, joined the Executive Committee of Free Constitutional Party, he who later dissociated himself from the party after the fame on the expense of the party, he then established a new party known as New Free Constitutional Party. Bourguiba was also arrested, but the political analysis experts then believed that, it was a French plan to present him as a patriotic and credible candidate to the Tunisians in order to build the public confidence in him and his followers to qualify him as a pro-France to rule the country, with the evidence of the exclusion and assassination of all his opponents. Massive demonstrations took place requesting for the reforms in the protection system, which was strongly repressed by the French and resulted into the loss of many lives. (Aljazeera Encyclopedia, 2014;Muhammad al-Hādī, 1993, P. 119- 124).

Those events were coincided with the Second World War in its early years, and Tunisia was initially out of the war, however the German and Italian forces descending from Libya that resorted to Tunisia turned the place to become the battleground between them and the Allies, therefore, it resulted into a great material and more political destruction which was the removal of al-Munșif Bey who was truly Tunisian. (al-Mawsū'ah alTunisiyyah). The reason for the impeachment was his request for a number of demands, among which are: Equality of salaries and wages between Tunisians and French employees, participation of Tunisians in monitoring the budget revenues and expenditures, abolition of the Waqf Land Ordinance, removal of all obstacles preventing Tunisians from owning rural lands and making education compulsory for all Tunisians and teaching Arabic in all schools. He also formed a general government headed by Muhammad Shanīq which comprised of national ministers, most importantly Mahmūd al-Mātirī the former head of new constitutional free party as the Minister of Interior, without consultation with the French authorities. He rejected as well the French racist procedure against Tunisian Jews by putting yellow star on them in order to distinguish them from the rest of the population. He told the French that Jews were like all other Tunisian Muslim citizens. After the impeachment of the Bey, Bourguiba sided with the allies. (al-Mawsū'ah al-Tunisiyyah). Then, Tunisian General Labor Union led by FarhātHashād emerged and played an important role in the national movement and formed a government of negotiations in which the New Free Constitutional Party participated without reaching an agreement. Subsequently an armed resistance broke up, which was approached by the government with a fierce war and eventually led to the assassination of FarhātHashād and some members of national movement. Finally, under the pressure of the workers and increase in crisis intensity, French eventually announced its intention to give Tunisia independence. (Muhammad al-Hādī, 1993, P. 130-131-133).

\section{Form of Tunisian Government and Society during Independence: A Prelude of Social Change}

New Free Constitutional Party took control of the power by winning all seats in the Council which enabled the party to form a government headed by Bourguiba. However, some of the portfolios were awarded to Tunisian General Labour Union as a reward for its standing with Bourguiba against Bin Youssef. (Muhammad al-Hādī, 1993, P.135-138). The genesis of the conflict between the old and new divisions of the Free Constitutional Party laywith the argument on language and religious identity, where the old division which is represented by bin Yūsuf and al-Tha'alabī used to swear in its Muslims candidates by Qur'an and Jewish candidates by Torah, while the new division was secular and Western in identity and interest. (Muhammad al-Hādī, 1993, P. 120, 129). Bourguiba abolished monarchy system and became president of the republic. He issued series of lawsbefore the establishment of the republic among which are: issuing of personal status code that prohibited polygamy, dissolving of Awqaf, Unification of judiciary, incorporation of al-Zaytūn̄ religious system of education into a mandatory secular public system and the establishment of National Army and Security. Thus, all the systems of the state became under the control of a single order of the greatest al-Mujāhid.) Sayfuddin, 2013). The party tried to take control of the public and cultural organizations and the unions as well, hence he dominated the Farmers Union, Women's Organization and the Student Union. Bourguiba was able to neutralize the unions and manipulate them in the application of his economic policy, which depends on borrowing from the World Bank and America, to which Bourguiba openly declared his loyalties, even in its war against Vietnam and its invasion of Lebanon.(Muhammad al-Hādī, 1993, P. 133).

\section{Analysis and Observation}

It is obvious that Tunisia has been governed since its independence until jasmine revolution by the same elite and party; two rulers but one authority, as Ibn 'Alī was an extension and choice of Bourguiba, so there has been no exchange of power between the period that closeto six decades. 
Bourguiba's speech about the family code that forbade polygamy and restricted divorce on court decision intended to change the structure of the family and shape its present and future status differently from the previous form. He also intended to cancel the sanctity for the sacred symbols, as hetried to extract that holiness for himself and equated himself with the divine law at this point. He considered himself as Imam that is authorized to decree anything, therefore he tried to lessen the importance of two essential and fundamental pillars of Islam, as he called for allocating the money made for Hajj for Social Solidarity Fund or spending iton manufacturing and development of the country and urged the citizen to visit the tomb of companions in the country instead of going to hajj. He also explicitly called for the break of fasting during the day of ramadhān in one of his speech in Qayrawani and requested for the expansion of al-Rukhșa and adoption of different views in understanding the objectives and results of fasting and then gave a decree to force the army and police personnel to break their fasting during Ramadan. (ShawqiBu'azzah, 2009).Not only did he interfere in the religious affairs of the people, but he also tampered with their customs by breaking their allegiance to their families through massive displacement, imprisonment and punishment for those who called for the family allegiance or called to the claim of their lands. Family allegiance to Bourguiba was considered as a strong competitor and threat that disrupt the path of modernity, because it is based on tribalism and property ownership. However, Bourguiba was the pioneer of ideology of changing Tunisia from its original identity to become as France,so he dispersed the tribes and abolished the veil. All the functions of the social institutions were broken, violated and abolished for the benefit of one individual represented in the person of Bourguiba, while he also maintained his regard. However, explicit and exact roles and functions require a clear responsibility and clear accountability, but that was not the case in this patriarchal system, where Bourguiba's policy was based on consolidating and concentrating of powers in the hand of a single person, so efficiency is not a requirement in patriarchy.1024 framework made by Bourguiba was the framework of personal patriarchal legitimacy, which made him the father of all, and based on the trust of the people in his person, and from his personality he derived the legitimacy, not from institutionalism or from work and efficiency, so legitimacy was inherited in this customized form, rather than to be gained from democratic and institutional basis.

Bin 'Ali announced his presidency due to the poor state of Bourguiba's health that led to incapacity to carry out the responsibility and swore in on the same day. He began to reassure the public with the promise to abolish the system of presidency for life and to establish political pluralism. He canceled the court of the state security, released the Islamist and unionist detainees. However, he maintained the formation of government, and amended the Constitution to increase the power of the President of the Republic. He organized a presidential election through which he became president. In this way Bin 'Alī assumed power early 1990 and appointed his close associates in the most important institutions of the country, at the same time he allowed the formation of new associations and political parties that would be regulated by the law and monitored their source of funds.Among the common procedure: no association or institution including Human Right Association, professional structures of lawyers, judges and journalists can be established or engaged in any activity without connection with the ruling party, even the sports associations were required to get their members of administrative councils recommended from the ruling party, or else it will be dissolved. In addition, a person or an institution is not allowed to contest for any political post unless he gets certificate of eligibility with the endorsement of Interior Ministry, which would not be issued to the opposition party. Bin 'Alī continued running for election without rivals and succeeded by nearly 100 percent, as a matter of fact that Bin 'Ali was a security man who established a police apparatus with a total of 537,777 policemen, besides the undeclared forces in a country of 10 million people, among which more than one million are in the Diaspora. (Tunisia-Sat Forum; Thomas Schiller, 2011, p.6 ).

Accumulation of psychological problems in Tunisian society was so high and about to explode-Normalization of relation with Zionist state improved to the extent that the exports of Zionists to Tunisia increased significantly compare to the exports of Tunisia to the Zionist state. Anti-Terrorism Act, under which many were arrested with the accusation of discussing about what was going on in Iraq and Palestine or reading from the pages of resistance. Actually, there has been some kind of economic growth and openness, and various social programs, such as National Solidarity Fund and the Public Car, which aimed to alleviate poverty and provide facilities for the middle classes. Tunisia signed a partnership agreement with European Union, which led to the bankruptcy of many small and medium enterprises and dismissal of approximately 357,777 workers as a result of the conditions imposed by European Union for the rehabilitation of institutions and the application of acceptable European standards in the production process, and the custom barriers to foreign goods which were competitive with Tunisian products have been abolished. 
As a result of these privatizations, State resources have decreased and public debt escalated. Hundreds of public institutions were also affected, resulting in thousands of workers' dismissal and deterioration of work conditions.

Therefore, unemployment rate was particularly high among young people and graduates, which made them resorted to work under the slavery of employers for a limited time without any rights. The president held a referendum for the constitutional amendments that would enable him personally to enjoy judicial immunity and the possibility of extending his tenure, which would lead to a solution to a problem that people do not feel. Local modernization project was carried out from a liberal western perspective, in French way specifically, and there was emergence of ruling party's elites adapted to Western ideas, and also the emergence of new elites highly popular adopted the Western ideas, who their terms of reference was the nature of the power to which they belong. There was a full cooperation between the party and other institutions of the state parliament and organizations where the head of the party is the head of state. The party was the source of the ideology of the state, which generates harmony and cooperation between legislation and executive and then party discipline.

\section{Concluding Remarks}

After this intellectual tour about the change in Tunisia since before the French occupation till pre-revolution of dignity or jasmine, we conclude with the following results: Change occurs in any society in one of the following ways:

$\square$ By law

$\square$ By principles of education

$\square$ By force

Change occurs for many purposes, including: Human need for dignity and personal respect, social need for justice and political need for freedom. What usually changes in man is conduct, by changing the values governing behaviours, and the countries and institutions adopt change in the vision of the state, therefore it reflects in the objectives of its institutions and the nature of central authority's relationship with the other parties. The area of change is identity, which is language and religion, with control over the economy. In a nutshell, there is a definite effect between the system adopted by the authority and the impact of this system on the structure of society economically and morally; the authority or system has impact when a vision is adopted, and leaders are promoted to implement and apply it in various fields. Thus, there were Tunisia reformers, such as Khayruddīn al-Tūnisī who adopted the change through education and principles, so he worked on reform and renaissance through educational development. As for the change by law and power, it was led by al-Habīb Bourguiba, who built his reformist foundations in Tunisia on the basis of its uniqueness, specificity and the role model of France and West. The research confirms that Tunisia as one of the other great cities of Islam, has maintained its centrality as a defensive force for Islam against European enemies; It was a province and military of Ottoman caliphate. Responsibility is divided between the government in the capital and community leaders, especially the religious mystics and the pious ones in suburbs and corners where their places of worship. The rudder of life used to be controlled, especially in crises and disasters, by institutions such as endowment foundation (al-Ahabās), alZaytūnah and Zawāyā in rehabilitating and directing people to achieve socio-economic security, while the defense security is done by the government. However, when the imbalances occurred and the state resources entrusted to their relatives and thieves, then Tunisia was conquered and occupied.

Dualism of power and right has governed man since ever, including Tunisia. Man has a basic innate valued system that guides him and clarifies the limits of relationship with the others. This value usually affected by environment and institutions of society (family, government, economy, education and religion) in which people live. As the Prophet said, "I have left you on a clear white plain, whose day is like its night, anyone who deviates from it will go astray."Thus, it is natural that whenever a man deviates from innate nature he goes astray. We found during our intellectual tour on Tunisia history that, whenever there is imbalance in competences the rights would be lost. Imported innovations from the West or East are good if they were selected, adjusted and placed within the original framework of the society, therefore constants remain and life becomes modern. However, if the variables are given the opportunity to take control of the customs that will surely cause a lot of problems and change the principles and no positive result is guaranteed. We mean by variable here: personal interests that are governed only by self-love, egoism and passion that may blind to see the rights, lust for the fame and power that misleads the understanding, Love of money and insatiability that lead to injustice and emergence of patronage and paralysis and customization, or the control is given to the new rules that produce new laws which are not governed by the old standards and references. 
Thus there will be imbalances in every aspects and categories. Prophet (SAW) said: "Forgive the people with high moral values when they slip but not what calls for the infliction of Hudud." When the law does not apply to everyone and the constants change, it will definitely result in corruption. It is just as if we are plowing the sea and reaping the wind. According to Hadith of prophet, where he said: "Indeed what destroyed the people before you were just that when a person of high rank among them committed a theft, they spared him; but if the same crime was done by a poor person, they inflicted the prescribed punishment on him. I swear by Allah that if Fatimah daughter of Muhammad should steal, I would have her hand cut off."

Actually, there were constants which are known to the public as the principles governed the cities and outskirts of Islam, which are flexibly interactive with the environment and time. Hence their applications came in different forms, accommodating all, and in line with their customs, which governed by Allah's word, where he said: "Hold to forgiveness, command what is right, and turn away from the ignorant." (Surah al-'Arāf, 199).

So the image of Tunisian Muslim community here is an authentic image of a long period of time, because people's life moved within the comprehensive and clear Islamic framework, despite that the authorities were often non-consultative and undemocratic, however society still remained active, productive and institutionalized. Subsequently, when the evil and unknown agents ruled the people, their reactions came unfavorably. We found that the interference of Tunisian government in the tribal system during Bourguiba's period, when he criminalized the act of belonging to the tribalism, dispersed the tribes into different places and imprisoned those who advocate tribalism; People replaced their previous allegiance to the tribe with their loyalty to different parties. Owing to the fact that a man needs faith and allegiance, for the both are instinctive and innate feature in human, any attempt to clash with the instinct and nature of the people and their cultural heritage will definitely create a big dramatic change in any societies, as it created the concept of centralization in our society, i.e. total abolition of the public roles, where all the public responsibilities being carried out by the state. Consequently, the system developed automatically into the next stage which can be described with the following words, autocratic, hierarchical and patriarchal system. Hence, the country was turned to family enterprises instead of geopolitical states.

Therefore, the Bourguiba's patriarchal system became systematic political approach, because it establishes patriotism for the state. He penetrated the family connection bybreaking the tribal loyalties. He disrespected religion and subjected it to change as the others, which gave the government the right of interference in the people's confidentialities and confiscating their freedoms. Rather than submit to celestial rules which everyone believes in its holiness and stability as it comes from Allah, in who everyone relies and believes in his justice, mercifulness and lordship, as there is no any exceptional relationship between Allah and men to give one class priority above the others, Allah says: "O mankind, indeed We have created you from male and female and made you peoples and tribes that you may know one another. Indeed, the most noble of you in the sight of Allah is the most righteous of you. Indeed, Allah is Knowing and Acquainted." (Surah al-Hujrāt: 13), we subject to the legislation of a human being like us, which raises the question of why it is he? Thus, the sanctity and human dignity guaranteed by human creation and instinct are lost, and the constants are shaken, as inconstancy cannot produce except inconstancy.

We strongly believe that Muslims possess feature that distinguished them from the others; whenever it is believed that Islam and Muslims have been eliminated, then you see Muslims rise up as the phoenix bird rises from the ashes, and prove the enemies' estimations wrong. Surely, Allah's absolute power is over the limited and restricted human power. Thus, Tunisian society disagreed with the people's expectations and returned again to turn down the westernization and vandalism. Why did not Tunisians end up in becoming Frenchmen after this strenuous work for 60 years? Why do they break the rules of logic in survival and advancement again? Why do they evolve and change, but they always return to the starting point and to the first formulation? Why not die the idea of Islamic nation? Why even the generations that the colonizers have made under their eyes and nurtured and trained in their traditional institutions, and whose mothers' tongue has become the western language, many of them do return to what they have been distanced from? In our opinion, the idea of Islamic nation (Ummah) can never die, due to its linkage and connection with the idea of monotheism which Allah has granted Muslims to know. As long as this idea remains vivid, Muslims will remain alive, resisting death, because Allah's existence is eternal. Whoever adopts this doctrine will be intractable to death, even if all physical data necessitates his death. 


\section{References}

AlīWadiu Hassan. (2017). Hal Kana al-Isti'imar al-aorobi li-mantiqah al-'Arabiyyah amranIjabiyyah am Salbiyyah? Retrieved April 20, 2018, from https://dkhlak.com/was-european-mandate-good/

Abdullatif Muhammad Khalifah. (1992). Irtiqau al-Qiyam. Kuwait: al-Majlis al-Watani liThaqafahwalFununwalAdab.

Aljazeera Encyclopedia. (2014). Retrieved April 30, 2018, from http://www.aljazeer a.net/encyclopedi a/icon s/2014/9/17/

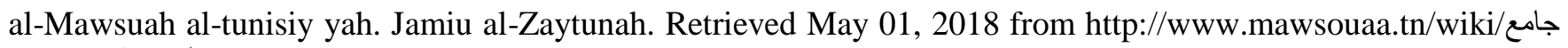
الزيتونة

Al-Zayla'īFakharudīn 'Uthmān. (n.d). Tabyīn al-HaqāiqSharhuKanz al-Daqāiq. (2nd ed.). vol 3. Bayrūt, Dār alMa'arifah.

Arkupal Acharya. (n.d). What are the advantages and disadvantages of centralization of authority? Retrieved May 07, 2018, from http://www.preservearticles.com/201101143291/advantages-and-disadvantagesof-centralisation-of-authority.html

benhenda-tcherno. (2009). Tunisia 'abra Tarikh. Tunisia-Sat Forum. Retrieved May 01， 2018, from https://www.tunisia-sat.com/forums/threads/771901/

Conveyancing and Law of Property Act 1881. Retrieved May 20, 2018, from http://www.legislati on.gov.uk/ukpga/Vict/44-45/41/enacted

Ghānim,al-Sayyid 'Abdu al-Muțțalib Ahmad. (2004). Mawsū'at al-Idārat al-'Arabiyyah al-Islāmiyyah, al-Idārat al-Mahliyyah, al-'Arabiyyah al-Islāmiyyah. (2nd ed.). al-Munașșamah al-Arabiyyah li tanmiyah alIdāriyyah.

Gisela Trommsdorff. (2000). Effects of Social Change on Individual Development: The Role of Social and Personal Factors and the Timing of Events. Retrieved May 10, 2018,from,https://pdfs. semanticscholar.or g/473a/12 516f8198758d5e70257865ff4fc8303602.pdf Hassan Husayn. (1373 A.H). Khulasah Tarikh Tunisi. (3rd ed.). Tunisia: Dar al-Kutub al- 'Arabiyyah al-Sharqiyyah.

Muhammad al-Hādī al-Sharif, (1993). Tarikh Tunisi min 'Usuru ma Qablah al- Tarikh. Tunisia: Dar Saras liNashr.

Muhammad Nab̄ilJāmi'u. (2009). 'Ilmu al-Ijtimā’i al-Mu'āṣirwawașāyā al-Tanmiyah, al- Iskandariyah, Dār alJāmi'ah al-Jadīdah.

RaguiAssaad. (2011). How will Tunisia's Jasmine Revolution Affect the Arab World? Retrieved April 27, 2018, from http s://www.brookings.edu/opinions/how-will-tunisias-jasmine-revolution-affect-the-arabworld/

Robert. L. S. \& Julian L. W. (1937). Introductory Sociology. J.B. Lippincott Company.

SayfuddinBu'alaq. (2013). Mashru'u al-Awqaf fi Tunis bayna al-Maslahah... Retrived May 09, 2018, from https://www.babnet.net/festivaldetail-74665.asp

ShawqiBu'azzah. (2009). Al-Nass al-Asli li Khitab al-Habib Bourguiba. Retrieved May 07, 2018 from https://www.facebook.com/notes/habib-bourguiba/

Stanford Encyclopedia of Philosophy. (2008). Value Theory. Retrieved May 08, 2018, from https://plato.stanford.edu/entries/value-theory/

Taylor Thorn. (2017). What Is Social Change? Classroom. Retrieved May 20, 2018, from https://classroo m.synonym .com/what-is-social-change-12084124.html

Thomas Schiller. (2011). Tunisia - a revolution and its consequences. Kas International reports. Retrieved May 04, 2018, from www.kas.de/wf/doc/kas_22802-544-2- 30.pdf?11051613

Tunisian Personal Status Law. 